\title{
A Gross Morphological Study of Human Postmortem Pancreas in Bangladeshi People
}

\author{
Ahmed Firoz $^{1}$
}

\begin{abstract}
:
Context: Incidence of pancreatic disease increases day by day in Bangladesh. Recent advances in pancreatic surgery and search for new techniques toward investigation of pancreas are demanding a review of the morphology of the pancreas in Bangladeshi people.
\end{abstract}

Objective: To establish a gross morphological standard of pancreas in Bangladeshi people.

Study design: A descriptive type of study.

Place and period of study: The study was carried out in the department of Anatomy, IPGM\&R, Dhaka from November1991to May1992.

Materials: 40 (Forty) pancreases from Bangladeshi cadaver of either sex were taken for the study.

Method: The collected samples were divided according to different age and sex and comparative studies were done between different age and sex groups.

Result: For both the length and weight of the pancreas, there were no significant differences between male and female in the same age group and in between group $B$ and $C$ in the same sex. Significant differences were found in the same sex when compared between group $A \& B$ \& group $C \& A$.

Conclusion: The observation and results of the present study are expected to standardize the morphology of pancreas in Bangladeshi people.

Keywords: Pancreas, morphology.

Introduction:

The pancreas is a soft lobulated, grayish pink, Jshaped mixed gland extending nearly transversely across the posterior abdominal wall, behind the stomach, from the duodenum to the spleen in the epigastric and left hypochondriac regions ${ }^{1}$. A variety of pancreatic diseases like pancreatic carcinoma, pancreatic calculi, chronic pancreatitis, pancreatic calcification etc are prevalent in Bangladesh. Detailed anatomical knowledge is essential for proper treatment of pancreatic disease specially related to the surgical disorder.

\section{Materials and Methods:}

The present study was carried out on 40 human pancreas of Bangladeshi people of different age groups and sexes.

Human pancreases were collected from the dead bodies autopsied in the department of Forensic

1. Assistant Professor, Department of Anatomy, Dhaka National Medical College, Dhaka.

Correspondence: Ahmed Firoz
Medicine in Dhaka Medical College from November 1991 to May1992. This was done within 12 to 36 hours of death, discarding the samples showing considerable signs of decomposition. During collection, approximate age, sex and cause of death were noted from record book. The samples were collected from unclaimed dead bodies. Approximately healthy individuals were selected as the subject for collection discarding those who were apparently ill or debilitated. Then each specimen was marked with a code number for individual identification. The specimens were collected along with duodenum and spleen. After removal from the body, unwanted tissues were cleared and gently washed out in normal saline.

\section{Grouping of the samples :}

The collected samples were divided into 3 groups depending upon age.

Group A : 5-20 yrs

Group B : 21 - 40 yrs

Group C : $41-65$ yrs. 
Each group was again subdivided into two subgroups depending upon their sex. Detailed grouping and distribution for morphological study were shown as follows in Table-I.

Table-I

\begin{tabular}{lccc}
\hline $\begin{array}{l}\text { Group \& age } \\
\text { in years }\end{array}$ & $\begin{array}{l}\text { No. of } \\
\text { cases }\end{array}$ & Sex & M/F \\
\hline A & 13 & M & 8 \\
$(5-20)$ & & F & 5 \\
B & 15 & M & 10 \\
$(21-40)$ & & F & 5 \\
C & 12 & M & 8 \\
$(41-65)$ & & F & 4 \\
\hline
\end{tabular}

\section{Measurement of length :}

Immediately after collection, the length of the pancreas was measured with the help of string and a meter scale. The length of the pancreas was taken from the duodenal margin of the head to the tail in its different surfaces and the average length was taken.

\section{Measurement of weight:}

Before measuring the weight of the pancreas, it was detached from the duodenum and the spleen and it was dried by blotting paper and weighed by an analytical balance.

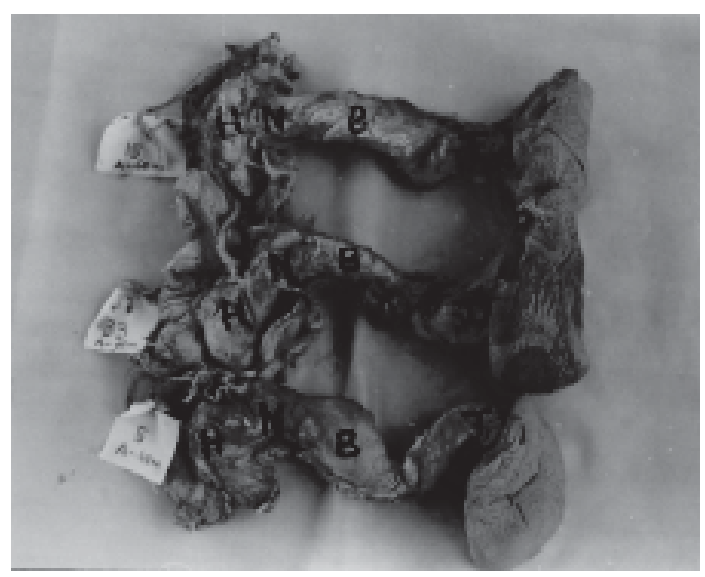

Fig.-1: Showing the morphology of pancreas. ( $\mathrm{H}=$ Head, $\mathrm{N}=$ Neck, $\mathrm{B}=$ Body, $\mathrm{T}=$ Tail $)$
Results:

Table-II

Results of the pancreatic length and weight:

\begin{tabular}{lcccc}
\hline $\begin{array}{l}\text { Group } \\
\text { (Age) }\end{array}$ & $\begin{array}{c}\text { Subgroup } \\
(\text { Sex })\end{array}$ & $\begin{array}{c}\text { Number } \\
(\mathrm{n})\end{array}$ & $\begin{array}{c}\text { Length in cm } \\
\text { Mean } \pm \text { SE }\end{array}$ & $\begin{array}{c}\text { Weight in gm } \\
\text { Mean } \pm \text { SE }\end{array}$ \\
\hline A $(5-20$ & Male & 8 & $14.94 \pm 0.60$ & $59.38 \pm 4.68$ \\
years $)$ & Female & 5 & $14.20 \pm 0.87$ & $57.00 \pm 4.68$ \\
B (21-40) & Male & 10 & $18.20 \pm 0.69$ & $94.10 \pm 4.67$ \\
years & Female & 5 & $17.20 \pm 0.25$ & $91.80 \pm 2.33$ \\
C (41-65 & Male & 8 & $19.13 \pm 0.71$ & $103.25 \pm 4.43$ \\
years $)$ & Female & 4 & $17.13 \pm 0.24$ & $92.50 \pm 3.18$ \\
\hline
\end{tabular}

Statistical analysis done by unpaired student's "t" test.

$\mathrm{n}=$ Number of specimen, SE $=$ Standard error

$\mathrm{P}<0.2$; Length, between group $\mathrm{A} \& \mathrm{~B}$ (Female)and $\mathrm{C} \& \mathrm{~A}$ (Female)

$P<0.01$; Length, between group $A \& B$ ( Male)

$\mathrm{P}<0.001$; Length, between group $\mathrm{C} \& \mathrm{~A}$ (Male); weight, between group A\&B (Male) and weight, between C \& A (Male \& Female)

$\mathrm{P}<0.05$; Weight, between group $\mathrm{A} \& \mathrm{~B}$ ( Female)

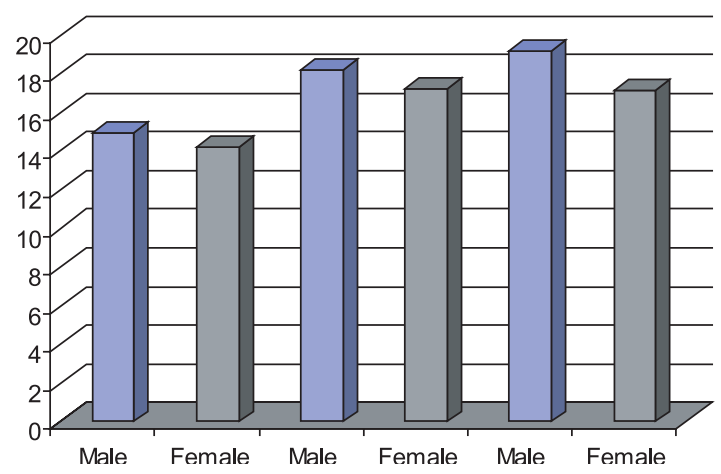

Fig. -2 : Bar-diagram showing the pancreatic length in $\mathrm{cm}$

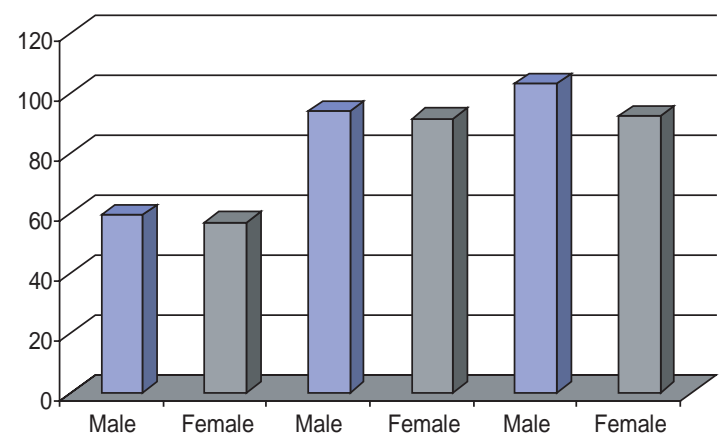

Fig.-3 : Bar-diagram showing the pancreatic weight in $g m$. 
In male the mean length and weight of pancreas in Group A, B and C were $14.94 \pm 0.60 \mathrm{~cm}, 59.38 \pm 4.68$ $\mathrm{gm} ; 18.2 \pm 0.69 \mathrm{~cm}, 94.1 \pm 4.67 \mathrm{gm}$ and $19.13 \pm 0.71 \mathrm{~cm}$, $103.25 \pm 4.43 \mathrm{gm}$ respectively. The pancreatic length and weight were significantly higher in group $B$ than that of the group $A$. The $P$ values were $P<0.01$ and $\mathrm{P}<0.001$ respectively. In group $C$ pancreatic length and weight were significantly higher than those of group $B$ and $P$ values were $P>0.3$ and $P>0.5$ respectively. The pancreatic length and weight in group $C$ were greater than that of group $A$ and the differences were highly significant $(P<0.001)$ in both cases.

In female the mean length and weight of pancreas in Group A, B and C were $14.2 \pm 0.87 \mathrm{~cm}, 57 \pm 4.90 \mathrm{gm}$ ; $17.20 \pm 0.25 \mathrm{~cm}$ and $91.80 \pm 2.33 \mathrm{gm}$ and $17.13 \pm 0.24 \mathrm{~cm}$ and $92.5 \pm 3.18 \mathrm{gm}$ respectively. The pancreatic length and weight were significantly higher in group $B$ than that of the group $A$. The $P$ values were $P<0.02$ and $P<0.05$ respectively. The pancreatic length in group $B$ was not significantly higher $(P>0.8)$ than that of group $C$. The pancreatic weight in group $C$ was not significantly higher $(P>$ 0.4 ) than that of group $B$. The pancreatic length and weight in group $C$ were higher than that of group $A$. The differences in case of length was significant $(P$ $<0.02$ ) and in case of weight was highly significant $(\mathrm{P}<.001)$.

In group A, pancreatic length and weight in male were higher than that of the female but the differences were not statistically significant. The $P$ values were $P<0.4$ and $P>0.7$ respectively. In group $B$, the pancreatic length and weight in male were higher than that of the female but the differences were not statistically significant. The $P$ values were $P>0.1$ and $P>0.6$ respectively. In group $C$, the mean length and weight of the male pancreas were in significantly higher than that of the female and $P$ values were $P$ $<0.5$ and $P>0.5$ respectively (Table-II, Fig. $2 \& 3$ ).

\section{Discussion:}

The average length of the adult male pancreas was $18.2 \pm 0.63 \mathrm{~cm}$ and of the adult female pancreas was $17.2 \pm 0.25 \mathrm{~cm}$. These values were higher than that of the values reported by Williams et al. ${ }^{1}$, Kimber et al. ${ }^{2}$, Basmajian ${ }^{3}$, Minn $^{4}$. The present result is more or less equal to the value reported by Edward ${ }^{5}$ but less than that of the value reported by Garven ${ }^{6}$.

In the present study, the average weight of the adult male pancreas was $94.1 \pm 4.67 \mathrm{gm}$ and of the adult female pancreas was $91.8 \pm 2.33 \mathrm{gm}$. These values were more or less equal to that values reported by Gardnere ${ }^{7}$ and Garven ${ }^{6}$ but greater than that of the values reported by Kimber ${ }^{2}$, Mann ${ }^{8}$ and Williams et al. ${ }^{1}$ but the average weight obtained in the present study was lower than that of the values reported by Basmajian ${ }^{3}$.

\section{Conclusion:}

The observation and results of the present study are expected to standardize the morphology of pancreas in Bangladeshi people.

\section{References:}

1. Williams PL, Warwick R, Dyson M, Bannister HL, editors. The pancreas. Gray's Anatomy. $37^{\text {th }}$ ed. Edinburgh:Churchill Livingstone;1989. p. $1140-53$.

2. Kimber DC, Gray CE, Stackpole CE. Human pancreas. Anatomy and physiology. $14^{\text {th }} \mathrm{ed}$. New York: The Macmillian Company; 1961.p.495.

3. Basmajian JV. Grant's method of Anatomy. $8^{\text {th }}$ ed. Baltimore: The Williams and Wilkins Company; 1972. p.429.

4. Minn RMHM, editor. The pancreas. Last's Anatomy. $10^{\text {th }}$ ed. New York: Churchill Livingstone; 1990. p.351.

5. Edward LF. The pancreas. Concise anatomy. $2^{\text {nd }}$ ed. New York: McGraw-Hill; 1959. p.420.

6. Garven HSD. Pancreas. A student's histology. $2^{\text {nd }}$ ed. Edinburgh:E\&S Living stone Ltd;1962.p.444.

7. Gardnere E, Gray DJ, Rahilly RO. The pancreas. Anatomy. $2^{\text {nd }}$ ed. Philadelphia: WB Saunders Company;1960. p.580.

8. Mann CV, Russell RCG, editors. Pancreas. Bailey \& Loves short practice of Surgery. $21^{\text {st }}$ ed. London: Chapman \& Hall;1991. p.1077. 